\title{
Pengaruh Model Ecopedagogy terhadap Aspek Kompetensi Ekologis Siswa SMA
}

\author{
Puri Nofianti ${ }^{1}$, Sumarmi ${ }^{1}$, I Komang Astina ${ }^{1}$ \\ ${ }^{1}$ Pendidikan Geografi-Universitas Negeri Malang
}

\begin{tabular}{l}
\hline \hline INFO ARTIKEL \\
\hline Riwayat Artikel: \\
Diterima: 26-07-2019 \\
Disetujui: 18-09-2019 \\
\hline
\end{tabular}

\section{Kata kunci:}

ecopedagogy model; ecological competence, high school student; model ecopedagogy; kompetensi ekologis; siswa SMA

\author{
Alamat Korespondensi: \\ Puri Nofianti \\ Pendidikan Geografi \\ Universitas Negeri Malang \\ Jalan Semarang 5 Malang \\ E-mail: purinofianti94@gmail.com
}

\section{ABSTRAK}

\begin{abstract}
This research aim is to know the effect of ecopedagogy model on aspect of ecological competence high school students. This study was quasi-experimental research with the Pretest-Posttest Nonequivalent Control Group. The research subjects consisted of two classes namely XI IIS II as the experimental class and XI IIS I as the control class. This study was conducted at MAN 1 Sintang. The data analysis used independent sample t-test which showed that the ecopedagogy model had an effect on ecological competence students. From the results of the posttest, it can be seen that the experimental class has higher value rather than the control class.
\end{abstract}

\begin{abstract}
Abstrak: Penelitian ini bertujuan untuk mengetahui pengaruh model ecopedagogy terhadap aspek kompetensi ekologis siswa SMA. Penelitian ini merupakan jenis penelitian eksperimen semu dengan Pretest-Posttest Nonequivalent Control Group. Subjek penelitian terdiri dari dua kelas yaitu XI IIS II sebagai kelas eksperimen dan XI IIS I sebagai kelas kontrol. Penelitian ini dilakukan di MAN 1 Sintang. Analisis data menggunakan uji independent sample t-test yang menunjukkan bahwa model ecopedagogy berpengaruh terhadap kompetensi ekologis siswa SMA. Dari hasil posttest kelas eksperimen memiliki nilai lebih tinggi dibandingkan dengan kelas kontrol.
\end{abstract}

Isu mengenai kerusakan telah banyak didengungkan semua pihak saat ini. Perkembangan teknologi telah memberikan banyak dampak, baik positif maupun negatif. Hal yang patut diwaspadai adalah perubahan yang terus menerus bergerak ke arah negatif. Pencegahan harus mulai dilakukan dari membentuk individu yang sadar akan keberlangsungan lingkungan untuk pembangunan berkelanjutan. Banyak hal yang dapat dilakukan untuk keberlangsungan lingkungan yang berkelanjutan, salah satunya adalah melalui pendidikan yang diterapkan di sekolah untuk menciptakan generasi sadar lingkungan melalui environtmental education atau pendidikan lingkungan. (Sumarmi, 2008) menyatakan bahwa pendidikan lingkungan memiliki tujuan untuk membuat orang sadar dan peka terhadap lingkungannya. Sadar lingkungan dapat diartikan sebagai kesadaran yang berdasar pada hubungan positif individu dan sosial dengan lingkungan yang lebih memperhatikan keteraturan hukum dalam ekologi.

Penerapan environtmental education diharapkan dapat memberikan perubahan terhadap kompetensi dasar siswa mengenai aspek ekologis untuk memperbaiki permasalahan lingkungan melalui pemberian pengetahuan untuk mengubah sikap dan meningkatkan keterampilan mengenai lingkungan. Menurut (Omran, Iraj, \& Yarmohammadian, 2016) Environmental Education is an active process that is an effort to increase awareness, knowledge and skills. Environmental education is also used in improving understanding and making decisions based on information and construction activities that can integrate all environmental components. Environtmental education yang diterapkan di sekolah diharapkan memberikan perubahan terhadap kompetensi yang berhubungan dengan aspek ekologi berupa aspek pengetahuan, aspek sikap dan aspek keterampilan. Aspek ekologi dapat digunakan untuk mengkaji memahami interaksi antara manusia dengan lingkungannya. Menurut (Fauzi \& Muryani, 2018) manusia memiliki jalinan atau hubungan dengan lingkungannya yaitu hubungan timbal balik, jadi memiliki keterkaitan dan saling memberikan pengaruh.

Pencapaian pembelajaran terkait aspek kompetensi ekologis membutuhkan model pembelajaran yang dapat menjadi jalan untuk pelaksanaannya. Pembelajaran ecopedagogy dapat dijadikan sebagai alternatif untuk peningkatan aspek kompetensi ekologis. Selain itu, model pembelajaran ini juga sesuai dengan identifikasi masalah yang terjadi pada kelas XI IIS MAN 1 Sintang yang mana pembelajaran masih berpusat pada guru. Pembelajaran yang menjadikan guru sebagai pusat ini memiliki kelemahan. (Prasetya, 2014) menyatakan bahwa pembelajaran yang memilih guru sebagai pusat pembelajaran akan membuat siswa memiliki kecenderungan pasif karena siswa hanya diposisikan sebagai penerima pengetahuan dan siswa sendiri tidak 
memiliki kontrol dalam proses pembelajaran. Berdasarkan latar belakang yang telah dipaparkan, penelitian ini bertujuan untuk mengetahui pengaruh model ecopedagogy terhadap aspek kompetensi ekologis siswa SMA.

\section{METODE}

Penelitian ini bertujan untuk mengetahui apakah model pembelajaran ecopedagogy ini berpengaruh terhadap aspek kompetensi ekologis siswa SMA. Rancangan yang digunakan adalah menggunakan (quasi eksperimen) menggunakan pretestposttest nonequivalent controlgroup desaign. Penelitian ini memiliki variabel bebas berupa model pembelajaran ecopedagogy, sedangkan aspek kompetensi ekologis memiliki posisi sebagai variabel terikat yang memiliki sub variabel berupa aspek pengetahuan terkait ekologi, aspek sikap ekologi dan aspek keterampilan ekologi.

Sebelum melakukan analisis untuk menguji hipotesis, akan dilakukan terlebih dahulu dua uji berupa normalitas dan uji homogenitas yang digunakan sebagai syarat sebelum dilakukannya uji hipotesis atau uji prasyarat. Uji prasyarat normalitas yang dilakukan adalah menggunakan uji normalitas Shapiro-Wilk yang nantinya akan menentukan analisis data berdistribusi normal atau tidak. Uji homogenitas berfungsi untuk mencari tahu apakah data yang diuji memiliki varians data yang homogen atau tidak dilakukan dengan menggunakan levene's test for equality of variences. Analisis data dengan mengguanakan Independent Samples T-Test memiliki taraf signifikasi $5 \%$.

\section{HASIL}

\section{Aspek Pengetahuan dalam Kompetensi Ekologis}

Analisis data menggunakan uji independent samples t-test menyatakan model pembelajaran ecopedagogy memiliki pengaruh terhadap aspek pengetahuan dalam kompetensi ekologis pada siswa kelas XI IIS MAN 1 Sintang, ditunjukkan pada tabel berikut.

Tabel 1 Uji Hipotesis Independent Sample T-Test Aspek Pengetahuan dalam Kompetensi Ekologis

\begin{tabular}{cc}
\hline Gain Score & Sig. (2-tailed) \\
\hline Equal variances assumed &, 003 \\
\hline
\end{tabular}

Bedasarkan tabel 1 uji statstik di atas diketahui bahwa uji independent samples t-test gain score diperoleh nilai sig kurang dari 0.05 yaitu $0,003<0,05$. Dapat disimpulkan bila H1 dapat diterima yang artinya model pembelajaran ecopedagogy berpengaruh terhadap aspek pengetahuan dalam kompetensi ekologis siswa di MAN 1 Sintang.

Tabel 2. Rerata Pretest, Posttest dan Gain Score Aspek Pengetahuan dalam Kompetensi Ekologis

\begin{tabular}{lll}
\hline \multirow{2}{*}{ Nilai } & \multicolumn{2}{c}{ Nilai Rerata } \\
\cline { 2 - 3 } Kelas Eksperimen & Kelas Kontrol \\
\hline Pretest & 71,42 & 69,65 \\
Posttest & 80,67 & 76,59 \\
Gain Score & 9,26 & 6,95 \\
\hline
\end{tabular}

Berdasarkan tabel 2 dapat diketahui kedua kelas penelitian memiliki perbedaan dalam hal perolehan nilai rata-rata. Peningkatan nilai lebih baik terjadi pada kelas eksperimen yang memperoleh nilai rerata mencapai 9,26 dengan rerata nilai pretest 71,42 dan rerata nilai posttest 80,67, sedangkan kelas kontrol memiliki nilai gain score (rerata) mencapai 6,95 pada nilai pretest dan rerata nilai posttest 76,59. Hal ini menunjukkan bahwa terjadi perbedaan peningkatan nilai pada kelas yang diberikan perlakuan dengan menggunakan pembelajaran ecopedagogy dengan kelas yang tidak diberikan perlakuan atau apa adanya.

Instrumen yang digunakan dalam pengukuran aspek pengetahuan dalam kompetensi ekologis diukur dengan menggunakan tes pengetahuan. Lebih lanjut, untuk pengukuran aspek pengetahuan dalam kompetensi ekologis sebelum perlakuan dalam penelitian, siswa terlebih dahulu diberikan uji pretest dan setelah perlakuan siswa diberikan posttest. Pretest diberikan pada siswa dengan tujuan untuk melihat kemampuan awal yang dimiliki siswa sebelum dilaksanakan pembelajaran menggunakan model ecopedagogy, sedangkan posttest dilakukan untuk melihat apakah model pembelajaran ecopedagogy memberikan pengaruh terhadap aspek pengetahuan dalam kompetensi ekologis. Secara lengkap, hasil analisis data pada aspek pengetahuan dalam kompetensi ekologis XI IIS 1 MAN Sintang dipaparkan pada gambar 1. 


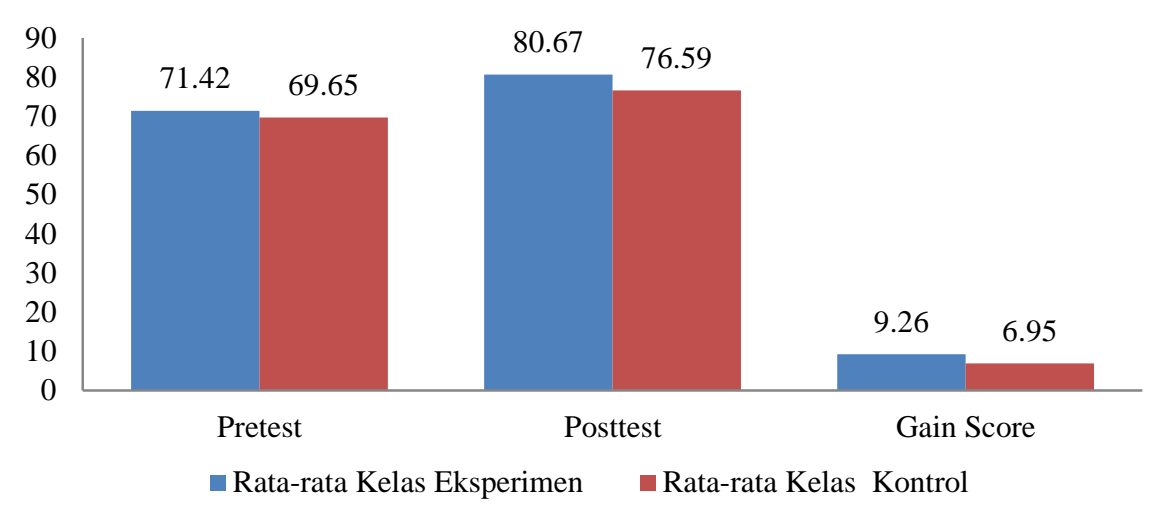

\section{Gambar 1. Rerata Nilai Pretest, Posttest serta Gain Score Aspek Pengetahuan dalam Kompetensi Ekologis}

\section{Aspek Sikap dalam Kompetensi Ekologis}

Analisis uji t yang dilakukan menyatakan bahwa model pembelajaran ecopedagogy memiliki pengaruh terhadap aspek sikap dalam kompetensi ekologis pada siswa kelas XI IIS MAN 1 Sintang, ditunjukkan pada tabel 3.

Tabel 3. Uji Hipotesis Independent Sample T-Test Aspek Sikap dalam Kompetensi Ekologis

\begin{tabular}{cc}
\hline Gain Score & Sig. (2-tailed) \\
\hline Equal variances assumed &, 000 \\
\hline
\end{tabular}

Bedasarkan hasil analisis uji statistik didapat hasil bahwa analisis uji independent samples t-test gain score memperoleh nilai sig kurang dari 0.05 yaitu hasil t-test $0,000<0,05$. Dapat disimpulkan bila H1 dapat diterima yang artinya model pembelajaran ecopedagogy berpengaruh terhadap aspek sikap dalam kompetensi ekologis siswa di MAN 1 Sintang.

Nilai rata-rata aspek sikap dalam kompetensi ekologis pada kedua kelas penelitian mengalami peningkatan. Kelas yang mendapatkan perlakuan (eksperimen) dengan model ecopedagogy memiliki nilai lebih baik dibanding kelas yang tidak diberikan perlakuan (kontrol). Berikut paparan nilai yang ditunjukkan pada tabel 4.

Tabel 4. Rerata Pretest, Posttest dan Gain Score Aspek Sikap dalam Kompetensi Ekologis

\begin{tabular}{lll}
\hline \multirow{2}{*}{ Nilai } & \multicolumn{2}{c}{ Nilai Rerata } \\
\cline { 2 - 3 } & Kelas Eksperimen & Kelas Kontrol \\
\hline Pretest & 71,93 & 72,13 \\
Posttest & 81,83 & 78,59 \\
Gain Score & 9,9 & 6,47 \\
\hline
\end{tabular}

Berdasarkan tabel 3 dapat diketahui kedua kelas penelitian memiliki perbedaan dalam hal perolehan nilai rerata. Sebelum dilakukan pembelajaran siswa terlebih dahulu diberi pretest, yang mana dari hasil tersebut nilai rerata pretest kelas kontrol lebih tinggi dibanding kelas eksperimen. Kelas kontrol mendapatkan nilai pretest 72,13, sedangkan kelas eksperimen 71,93. Setelah diberikan perlakuan, hal yang terjadi justru sebaliknya kelas eksperimen mendapatkan nilai jauh lebih baik dibanding kelas kontrol. Hal ini terbukti dari perolehan nilai posttest siswa yang diberikan perlakuan (eksperimen) dengan model ecopedagogy mendapatkan nilai 81,83, sedangkan kelas yang tidak diberikan perlakuan (kontrol) memperoleh nilai 78,59. Pengaruh penerapan model ecopedagogy ini sangat positif di kelas eksperimen dengan selisih rata-rata (gainscore) kenaikan nilai 9,9, sedangkan kelas kontrol mendapatkan selisih rata-rata (gainscore) lebih rendah dibanding kelas kontrol dengan nilai 6,47.

Instrumen yang digunakan dalam pengukuran aspek sikap dalam kompetensi ekologis diukur dengan menggunakan angket. Secara lengkap, rerata nilai pada aspek pengetahuan dalam kompetensi ekologis XI IIS 1 MAN Sintang dipaparkan pada gambar 2 . 


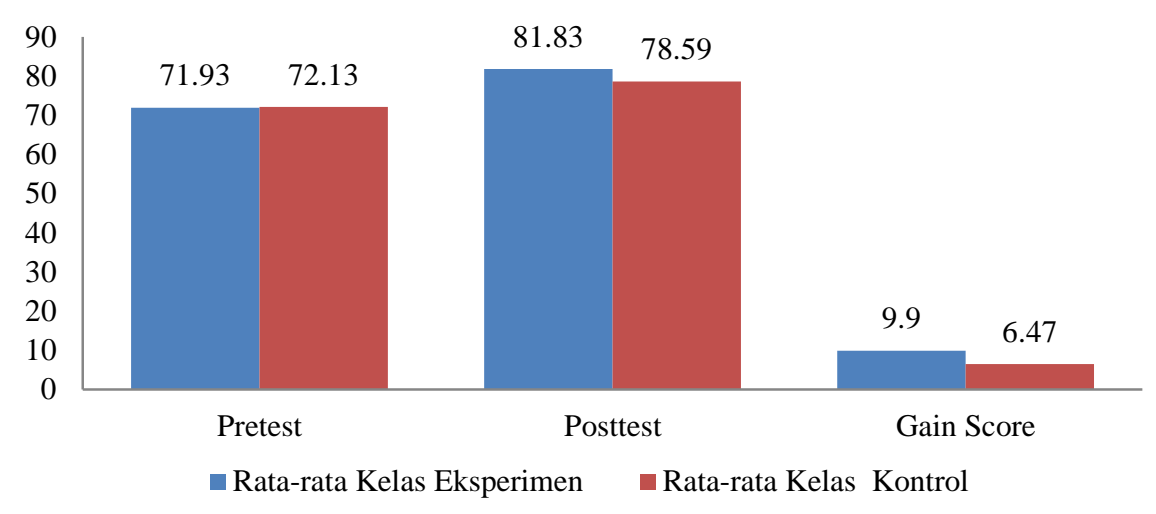

\section{Gambar 2. Rerata Pretest, Posttest Dan Gain Score Aspek Sikap dalam Kompetensi Ekologis}

Aspek Keterampilan dalam Kompetensi Ekologis

Analisis dengan uji independent samplie t-test menyatakan bahwa model pembelajaran ecopedagogy memiliki pengaruh terhadap aspek keterampilan dalam kompetensi ekologis pada siswa kelas XI IIS MAN 1 Sintang.

Tabel 5. Uji Hipotesis Independent Sample T-Test Aspek Keterampilan dalam Kompetensi Ekologis

\begin{tabular}{cc}
\hline Gain Score & Sig. (2-tailed) \\
\hline Equal variances assumed &, 049 \\
\hline
\end{tabular}

Berdasarkan hasil analisis uji statstik di atas diketahui bahwa analisis menggunakan uji independent samples t-test gain score diperoleh nilai sig kurang dari 0.49 yaitu $0,049<0,05$. Dapat disimpulkan bila H1 dapat diterima yang artinya model pembelajaran ecopedagogy berpengaruh terhadap aspek keterampilan dalam kompetensi ekologis siswa di MAN 1 Sintang.

Nilai rerata-rata aspek keterampilan dalam kompetensi ekologis pada kedua kelas penelitian mengalami peningkatan. Kelas yang mendapatkan perlakuan (eksperimen) dengan model ecopedagogy memiliki nilai lebih bagus dibanding kelas yang tidak diberikan perlakuan (kontrol).

Tabel 6. Rerata Pretest, Posttest dan Gain Score Aspek Keterampilan dalam Kompetensi Ekologis

\begin{tabular}{lll}
\hline \multirow{2}{*}{ Nilai } & \multicolumn{2}{c}{ Nilai Rerata } \\
\cline { 2 - 3 } & Kelas Eksperimen & Kelas Kontrol \\
\hline Pretest & 77,9 & 78,9 \\
Posttest & 85,77 & 84,75 \\
Gain Score & 7,9 & 5,9 \\
\hline
\end{tabular}

Berdasarkan tabel 6 diketahui nilai rerata pada kedua kelas penelitian memiliki perbedaan. Sebelum dilakukan pembelajaran siswa terlebih dahulu diberi pretest, yang mana dari hasil tersebut nilai rerata pretest kelas eksperimen lebih baik. Kelas kontrol mendapatkan nilai pretest 77,9 sedangkan kelas eksperimen 78,9. Setelah diberikan perlakuan hal yang terjadi justru sebaliknya kelas eksperimen mendapatkan nilai jauh lebih baik dibanding kelas kontrol. Hal ini terbukti dari perolehan nilai posttest yang siswa kelas yang diberikan perlakuan (eksperimen) dengan model ecopedagogy yaitu 85, sedangkan kelas yang tidak diberikan perlakuan (kontrol) memperoleh nilai 84,75. Pengaruh penerapan model ecopedagogy ini sangat positif diperoleh kelas eksperimen dengan selisih rata-rata (gainscore) kenaikan nilai 7,9, sedangkan kelas kontrol mendapatkan selisih rerata (gainscore) lebih rendah dibanding kelas yang memiliki status sebagai kontrol dengan nilai 5,9.

Capaian kemampuan keterampilan dasar siswa terkait lingkungan dalam penelitian ini diperoleh dari lembar penilaian keterampilan. Nilai keterampilan siswa diperoleh melalui lembar penilaian yang dilakukan siswa pada awal dan akhir pembelajaran melalui pretest dan posttest. Secara lengkap rerata data aspek pengetahuan dalam kompetensi ekologis XI IIS 1 MAN Sintang dipaparkan pada gambar 3. 


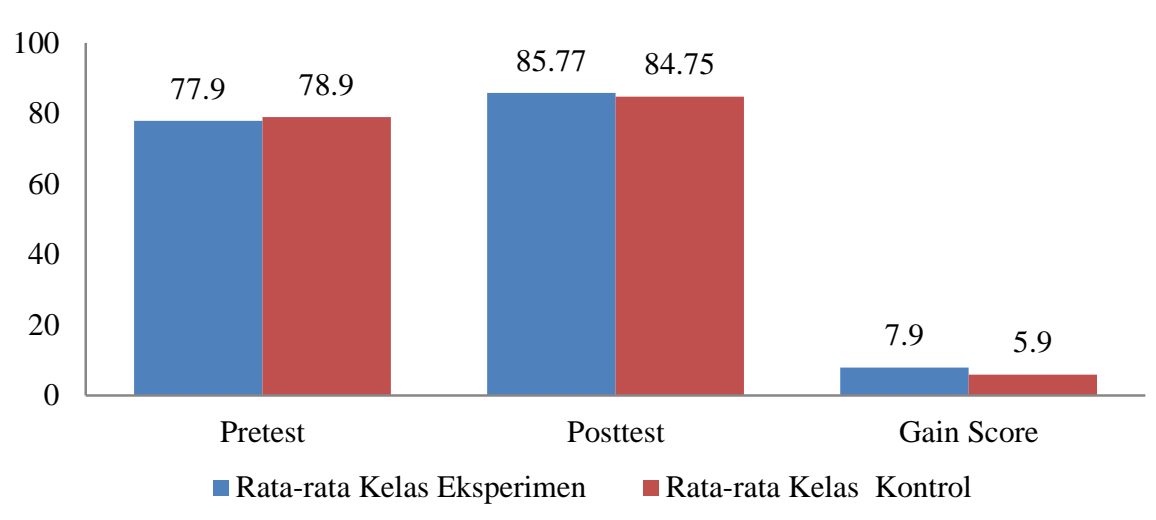

\section{Gambar 3. Rerata Pretest, Posttest Dan Gain Score Aspek Keterampilan dalam Kompetensi Ekologis}

\section{PEMBAHASAN}

\section{Pengaruh Model Pembelajaran Ecopedagogy terhadap Aspek Pengetahuan dalam Kompetensi Ekologis}

Pembelajaran ecopedagogy merupakan salah satu pembelajaran yang memperhatikan pembelajaran kontekstual menggunakan metode di luar lapangan. Model pembelajaran ini menuntut siswa untuk lebih memahami lingkungan sekitar mereka sebagai sumber belajar melalui sebuah permasalahan lingkungan. Model pembelajaran ini akan mendorong siswa untuk mengasah kemampuan analisis siswa dalam mengubah sebuah informasi menjadi sebuah pengetahuan untuk membantu mereka mengidentifikasi sebuah permasalahan lingkungan secara berkelompok melalui lima tahap sintak. Empat tahap awal sintak pada model pembelajaran ecopedagogy ini akan memperkuat siswa dalam aspek pengetahuan, yaitu (1) orientasi siswa yang difokuskan pada masalah, (2) melakukan sebuah kegiatan penelitian dan bersama-sama dengan menentukan sesuatu prioritas masalah, (3) membimbing sebuah penyelidikan yang dilakukan secara berkelompok, dan (4) membimbing sebuah kegiatan diskusi yang dilakukan dengan kelompok (Muhaimin, 2015). Empat tahap sintak ini akan dimulai dari penjabaran materi mengenai permasalahan lingkungan di lingkungan lokal siswa sampai pada tahap diskusi antar kelompok untuk sharing pengetahuan dalam penyelesaian masalah lingkungan di sekitar siswa melalui diskusi dan presentasi. Marpaung (2018) menyatakan bahwa pembelajaran melalui diskusi dan presentasi akan memperkuat peran guru sebagai fasilitator dan diharapkan dapat memberikan ruang tersendiri bagi siswa untuk peningkatan aktivitas dan kreativitas dalam pencarian informasi terkait materi yang disampaikan secara mandiri melalui pembelajaran kooperatif.

Pembelajaran kooperatif dengan menggunakan kelompok memang sangat dianjurkan dalam pembelajaran kurikulum 2013. Pembelajaran secara kelompok sendiri akan menunjukkan interaksi sesama teman sejawat yang akan membuat siswa belajar bersama dengan berbagi pengetahuan untuk menyelesaikan permasalahannya melalui kegiatan diskusi, saling berargumen, saling bertanya dan menyampaikan pendapat. Pembelajaran berbasis kelompok ini sejalan dengan teori pembelajaran konstruktivisme dari Vygotsky. Vygotsky adalah ilmuan yang melatar belakangi teori konstruktivisme sosial. (Suci, 2018) menyatakan bahwa Vygotsky menyarankan agar guru dapat melakukan kolaborasi dengan siswa serta memfasilitasinya untuk membangun pengetahuan melalui kegiatan diskusi, tanya jawab serta berdebat dengan teman sebaya.

Perlakuan yang diberikan dalam penggunaan model ecopedagogy ini akan mendorong siswa untuk mencari tahu sendiri fakta dan informasi terkait permasalahan yang di lapangan. Hal ini sejalan dengan teori dasar konstruktivisme. (Waseso, 2018) menyatakan bahwa esensi lain dari teori konstruktivis didalam kegiatan pembelajaran adalah ide-ide atau gagasan harus ditemukan sendiri oleh siswa dan informasi yang kompleks tersebut harus ditransformasikan serta diinterpretasikan sendiri oleh siswa dan mengubahnya menjadi pengetahuan. Melalui informasi yang diperoleh siswa di lapangan akan dianalisis, dipilah, dan ditransformasikan untuk tujuan pemecahan masalah dan solusi apa yang dapat diberikan mengenai permasalahan di lingkungan lokal tempat tinggal mereka.

\section{Pengaruh Model Pembelajaran Ecopedagogy terhadap Aspek Pengetahuan dalam Kompetensi Ekologis}

Pembelajaran menggunakan model ecopedagogy memiliki lima sintak yang akan mendorong dan memperkuat siswa memahami permasalahan lingkungan di sekitar mereka secara kontekstual, kontekstual dalam artian siswa melihat dan bersinggungan langsung dengan permasalahan tersebut pada wilayah lokal tempat tinggal siswa. Pada tahapan sintaks pertama sampai dengan keempat akan mendorong dan mendukung pengetahuan siswa dalam memahami permasalahan lingkungan berupa: (1) orientasi yang difokuskan melalui sebuah permasalahan oleh siswa, (2) melakukan kegiatan penelitian dan memutuskan sesuatu yang dapat dijadikan prioritas masalah, (3) membimbing sebuah investigasi yang kegiatannya dilaksanakan secara 
beregu/kelompok, dan (4) memandu sebuah diskusi/dialog yang dilakukan secara berkelompok (Muhaimin, 2015). Empat tahapan sintak ini dengan perlakuannya akan memberikan akses bagi siswa untuk mencari tahu sendiri informasi mengenai permasalahan yang terjadi di sekitar lokal tempat tinggal mereka yang akan mengubahnya menjadi sebuah pengetahuan dengan bantuan guru yang berperan sebagai fasilitator.

Informasi yang dapat diubah menjadi pengetahuan menggunakan pembelajaran ecopedagogy melalui perlakuan dalam tahapan sintak, sejatinya dapat memengaruhi pembentukan aspek sikap terutama yang memiliki hubungan dengan kompetensi dasar terkait ekologi (lingkungan). (Sari \& Mulasari, 2017) menyatakan bahwa pembentukan sikap akan dipengaruhi oleh pengetahuan, pengetahuan yang baik tentang sesuatu juga akan digunakan sebagai dasar dalam bersikap yang berarti pengetahuan berpikir memegang peranan penting dalam pembentukan sikap.

Sikap tidak bersifat bawaan melainkan dapat dibentuk dan diubah. (Gerungan, 2009) menyatakan bahwa sikap adalah sesuatu yang bisa dipelajari atau dibentuk dan bukan merupakan bawaan lahir yang tidak bersifat statis serta dapat diubah. Perubahan pada sikap sendiri dapat terjadi apabila terdapat sesuatu yang kuat sebagai pemicu perubahannya. Hal ini sejalan dengan teori perubahan sikap oleh Hovland Carl Ivler yang disebut sebagai teori Disonansi yang menyatakan bahwa perubahan sikap bukan tidak mungkin terjadi apabila terdapat sebuah informasi baru yang tidak sesuai dengan keyakinannya atau bertentangan dirinya (Ardiansyah, 2014).

Pemicu perubahan kompetensi sikap terkait ekologi dapat dilakukan melalui pembelajaran Geografi. Informasi yang siswa temukan melalui proses pembelajaran Geografi dengan model ecopedagogy di lapangan dengan materi mitigasi dan bencana alam akan mengarahkan siswa untuk menganalisis permasalahan lingkungan yang memiliki suspect bencana. Informasi mengenai permasalahan lingkungan ini akan mengonstruksi pengetahuan siswa untuk memahami kondisi lingkungannya dan menuntun jalan untuk mencari solusi serta bagaimana harus bersikap pro terhadap lingkungan untuk pelestarian yang berkelanjutan.

\section{Pengaruh Model Pembelajaran Ecopedagogy terhadap Aspek Keterampilan dalam Kompetensi Ekologis}

Sintak dalam model ecopedagogy yang dirujuk untuk peningkatan keterampilan dalam kompetensi ekologis adalah sintak dua hingga lima, meliputi (1) melakukan kegiatan penelitian dan menentukan sesuatu yang dapat dijadikan prioritas masalah; (2) membimbing sebuah penyelidikan yang dilakukan secara berkelompok; (3) membimbing sebuah diskusi yang dilakukan secara berkelompok; (4) mengembangkan permasalahan yang diidentifikasi dan menyajikannya menjadi sebuah karya (Muhaimin, 2015). Melalui model pembelajaran ecopedagogy siswa dilatih dalam hal keterampilan menganalisis permasalahan lingkungan yang ada di sekitar mereka melalui pembelajaran kontekstual. (Nilasari, Djatmika, Santoso, 2016) berpendapat bahwa kontekstual adalah pembelajaran dengan fokus menuntun siswa agar dapat mengonstruksi sendiri pengetahuannya, wajib dikaitkan dengan muatan materi yang diajarkan melalui situasi yang sesuai dengan kenyataannya di sekitar mereka sehingga dapat digunakan sebagai pegangan dalam pemecahan masalah lingkungan.

Model ecopedagogy akan menuntun kegiatan pemecahan masalah lingkungan langsung melalui kegiatan identifikasi Lapangan Dan Menggunakan Lingkungan Alam Serta Sosial Sebagai Sumber Pengetahuan. Pemecahan Masalah Sendiri Dalam Geografi (Sujiono, Budi Handoyo, 2018) menyatakan bahwa untuk memecahkan masalah siswa menggunakan pengalaman yang didapatnya dari lingkungan dan dijadikan sebagai materi. Siswa dapat menggunakan pengalaman dan pengetahuan yang diperolehnya dari lingkungan tersebut untuk aktivitas pemecahan masalah. Untuk melatih keterampilan dalam menganalisis adalah siswa harus sesering mungkin diberikan permasalahan yang dapat merangsang kemampuan berpikir.

Kegiatan yang dimunculkan untuk merangsang kemampuan berpikir dengan cara menentukan prioritas masalah akan menjadi tahap awal melatih keterampilan. (Sudarto, 2016) menyatakan bahwa urgensi keterampilan yang dimiliki seseorang akan memengaruhi efisiensi pekerjaannya. Jika seseorang memiliki tingkat keterampilan yang tinggi, maka pekerjaannya akan semakin mahir sesuai kemampuan teknis yang dimilikinya. Keterampilan yang dimaksud adalah keterampilan dalam menganalisis sebuah permasalahan lingkungan, menyampaikannya dan membuatnya menjadi sebuah karya. (Kurniawan, 2015) menyatakan bahwa pengembangan keterampilan analisis masalah dapat dilakukan melalui tiga aktivitas, yaitu (1) mengidentifikasi masalah, diselesaikan dengan menggunakan pengetahuan yang dimiliki sebelumnya, (2) menyusun sebuah perencanaan guna menyelesaikan permasalahan, dan (3) pelaksanaan rencana yang telah disusun kemudian nantinya dapat dianalisis ketepatan pengerjaannya dalam hal penyelesaian masalah.

\section{SIMPULAN}

Berdasarkan hasil analisis dan pembahasan di atas dapat disimpulkan bahwa (1) ada pengaruh model pembelajaran ecopedagogy terhadap aspek pengetahuan dalam kompetensi ekologis. Hal ini dibuktikan dengan hasil perhitungan menggunakan instrumen tes pengetahuan melalui analisis independent sample t-test diperoleh hasil 0,003 dalam artian 0,003 < 0,05, (2) ada pengaruh model pembelajaran ecopedagogy terhadap aspek sikap dalam kompetensi ekologis. Hal ini dibuktikan dengan hasil perhitungan menggunakan instrumen soal angket melalui analisis independent sample t-test diperoleh hasil 0,000 dalam artian $0,000<0,05$, dan (3) ada pengaruh model pembelajaran ecopedagogy terhadap aspek keterampilan dalam kompetensi ekologis. 
Hal ini dibuktikan dengan hasil perhitungan menggunakan instrumen lembar penilaian keterampilan melalui analisis independent sample t-test diperoleh hasil 0,049 dalam artian 0,049<0,05.

Berdasarkan hasil penelitian dipaparkan beberapa saran bagi guru Geografi dan peneliti selanjutnya yang akan menerapkan model pembelajaran ecopedagogy. Pertama, disarankan bagi peneliti selanjutnya agar melakukan penelitian pada semester ganjil pembelajaran karena membutuhkan waktu yang cukup panjang dalam perlakuan tahapan sintak. Kedua, model pembelajaran ini menggunakan media lingkungan secara langsung sebagai sumber belajar, diharapkan guru dapat lebih memperhatikan terkait koordinasi kegiatan lapangan agar lebih teratur dalam pencapaian tujuan pembelajaran.

\section{DAFTAR RUJUKAN}

Ardiansyah, A. (2014). Kekuatan Media Sosial dalam Kemenangan Politik. Al-Mishbah, 10(2), $283-298$.

Fauzi, C., \& Muryani, S. S. (2018). Hubungan antara Pengetahuan Lingkungan Hidup dan Prestasi Belajar Geografi dengan Sikap Peduli Lingkungan pada Siswa SMA Negeri di Kabupaten Karanganyar. Jurnal GeoEco, 4(1), 88-99.

Gerungan, W. A. (2009). Psikologi Sosial. Bandung: Rafika Aditama.

Kurniawan, H. (2015). Analisis Keterampilan Pemecahan Masalah pada Pembelajaran Matematika. Jurnal Pendidikan Surya Edukasi, 1(1), 67-73.

Marpaung, D. (2018). Penerapan Metode Diskusi dan Presentasi untuk Meningkatkan Minat dan Hasil Belajar Siswa di Kelas XI IPS-1 SMA Negeri 1 Bagan Sinembah. School Education Journal PGSD FIP Unimed, 8(4), 360-368. https://doi.org/10.24114/sejpgsd.v8i4.11375

Muhaimin. (2015). Membangun Kecerdasan Ekologis Model Pendidikan untuk Meningkatkan Kompetensi Ekologis.

Nilasari, E., Djatmika, E. T., Santoso, A. (2016). Pengaruh Penggunaan Modul. Jurnal Pendidikan: Teori, Penelitian, dan Pengembangan, 1(7), 1399-1404.

Omran, M., Iraj, M., \& Yarmohammadian, M. (2016). Investigating the Environmental Skill, Attitude, and Knowledge of Bojnourd Islamic Azad University Students. Journal of Earth, Environment and Health Sciences, 2(1), 28. https://doi.org/10.4103/2423-7752.181804

Prasetya, S. P. (2014). Memfasiltasi Pembelajaran Berpusat pada Siswa. Geografi, 12(1), 1-12.

Sari, N., \& Mulasari, S. A. (2017). Pengetahuan, Sikap dan Pendidikan dengan Perilaku Pengelolaan Sampah di Kelurahan Bener Kecamatan Tegalrejo Yogyakarta. Jurnal Medika Respati, 12(2), 1907-3887.

Suci, Y. T. (2018). Menelaah Teori Vygotsky dan Interdepedensi Sosial sebagai Landasan Teori dalam Pelaksanaan Pembelajaran Kooperatif di Sekolah Dasar. Jurnal Kajian Penelitian Pendidikan dan Pembelajaran, 3(1), $231-239$.

Sudarto. (2016). Keterampilan dan Nilai sebagai Materi Pendidikan dalam Perspektif Islam. Jurnal Al-Lubab, 1(1), 105-120.

Sujiono, Budi Handoyo, I. N. R. (2018). Memecahkan Masalah Geografi melalui Problem Based Learning. Jurnal Teori dan Praksis Pembelajaran IPS, 2(2), 66-72. https://doi.org/10.17977/um022v2i22017p072

Sumarmi. (2008). Sekolah Hijau Sebagai Alternatif Pendidikan Lingkungan Hidup dengan menggunakan Pendekatan Kontekstual. Jurnal Ilmu Pendidikan, 15, 19-25.

Waseso, H. P. (2018). Kurikulum 2013 Dalam Prespektif Teori Pembelajaran Konstruktivis. TA'LIM : Jurnal Studi Pendidikan Islam, 1(1), 59-72. 